\title{
Management of Classroom: Utilization of Learning Facilities and Teacher Performance on Learning Effectiveness
}

\author{
Fadhila Maulida Ismi*, Aan Komariah \\ Educational Administration Program \\ Universitas Pendidikan Indonesia \\ Bandung, Indonesia \\ *fadhilamaulidaismi@upi.edu
}

\begin{abstract}
This study aims to analyze and describe the effectiveness of learning through the use of learning facilities and teacher performance in management of classroom. The qualitative descriptive method was used as the main method in this research. The data collection process was performed by observation and interviews with a number of students and teachers using the snowball sampling technique at Integrated Islamic Elementary School Manba'ul 'Ulum. The result showed that the learning process could be effective if there was the availability of the optimal learning facilities. The effectiveness of learning is also inseparable from the performance of the teacher in its implementation. The conclusion of this study is that an effective learning process can be built from the maximum use of learning facilities and good teacher performance in management of classroom
\end{abstract}

Keywords-management of classroom, learning facilities, teacher performance

\section{INTRODUCTION}

Education is the most important thing in every country. Both developed and underdeveloped countries are, of course, very much influenced by the conditions of education inside them. Garis Besar Haluan Negara or GBHN (State Policy) states that education can encourage the improvement of the quality of human resources which will support national productivity [1]. Education can foster all the potential and talents that are useful for themselves and for society. Education is important for society. This nation needs to be educated and educated.

Education can be called as a strategic tool to improve people's lives. Through education, humans become intelligent, become capable, and have good attitudes. Education can also be called an investment that provides social benefits. Education also builds the dignity of a nation [2]. Based on the explanation above, it is necessary to improve the quality of education. Innovation in education must be carried out in an effort to improve the quality of education.
In the Indonesian education system, there are three education system, namely formal education, non-formal education and informal education. Formal education is said to be successful if the learning process in educational institutions is carried out properly and optimally. Learning facilities are one of the factors that support the success of education. The existence of learning facilities must be optimized. This is because the use of learning facilities is one of the determinants of the success of education.

The classroom is the most dominant place in the learning process. The ineffective situation in the classroom result in ineffective learning that is carried out. Thus, the classroom is very important in determining the success of the learning process at a certain level [3].

To increase the effectiveness of learning, teacher performance in managing the class is another important factor. Teacher performance is needed because it plays an important role in the learning process. Teachers need to create good learning strategies that determine the success of students in the learning process.

A teacher must understand the philosophy of learning itself. Teaching in the classroom is not just about sharing knowledge, but also provides examples of a number of behaviors that will become the personality of students. Therefore, teachers must be good at creating effective classroom conditions for teaching [4].

Apart from playing a role as a guide and acting as a role model, the teacher performance factor also greatly influences the effectiveness of learning [5]. The diversity of student characteristics is another factor that affects the learning process. There are two factors that shape student characteristics, namely internal factors and external factors. The internal factors of students include two aspects, namely physiology which is physical and psychological which is spiritual in nature. 
Apart from the factors mentioned above, there are many other factors that influence the effectiveness of learning. However, the factors chosen to be the main research material in this study were the utilization of learning facilities factor and the teacher performance factor in management of classroom. Both factors were interrelated and influence each other in many ways.

This study describes how learning process can be effective if it is supported by adequate learning facilities and good teacher performance in management of classroom. It is different from previous research which only used the learning facilities factor as the main subject in creating effective learning.

\section{LITERATURE REVIEW}

Learning facilities are an important factor in the provision of education that functions to provide convenience for students, teachers, and other education personnel [2]. Learning facilities are a tool or complement in supporting the process of teaching and learning activities carried out by students and teachers to facilitate or facilitate the learning process to be carried out.

Learning support elements related to learning facilities are that "there are three things that need our attention, namely learning media, learning equipment, and study rooms. These three components influence each other and contribute to learning activities and success" [6]. The use of learning facilities is the use of educational facilities and infrastructure to support the educational process, either directly or indirectly, which supports learning activities for the achievement of educational goals.

Classroom is a major infrastructure in educational institutions. Classroom is a group of people who do joint learning activities who get teaching from the teacher [6]. Management of classroom is a class management in which there are teacher skills to create and maintain a conducive learning atmosphere in achieving predetermined goals.

In management of classroom in learning, the teacher functions as a manager who leads the way of learning. Teacher leadership is the teacher's effort in encouraging, influencing, directing, guiding, and mobilizing students to play an active role in learning in achieving predetermined goals. There are several things that must be considered by the teacher in the implementation of learning so that learning can be more effective, namely the management of student seats, the volume of the teacher's words must be polite and can be easily understood by students in delivering learning material [7].

The teacher is a component in the teaching and learning process that plays a role in efforts to form potential human resources in the field of development. Therefore, teachers are one of the elements in the field of education that must play an active role and place their position as professionals, in accordance with the demands of an increasingly developing society [8]. Teachers must be able to manage the entire process of teaching and learning activities by creating learning conditions so that students can learn effectively and efficiently. Thus, the abilities that teacher must have are very complex in fostering their students so that the goals in teaching and learning can be achieved properly as expected.

Teacher performance is a job that can be achieved by a teacher in an educational institution in accordance with their duties and responsibilities in achieving educational goals. Teachers are not only teachers who transfer knowledge, but also as educators who transfer values and as guides who provide direction and guide students in learning. The duties and professionalism of teachers according to the Law of the Republic of Indonesia Number 14 of 2005 Article 20 letter a concerning teachers and lecturers, namely planning learning, implementing quality learning processes, and assessing and evaluating learning results.

Learning is the most basic activity of the entire educational process in school. Learning is a process in which there is a close relationship between teachers and students. This atmosphere is an ideal condition needed in every learning process [9]. In the teaching and learning activities, teacher performance has an important task for the success of teaching and learning activities, because the teacher is a figure who plays an important role which is expected to be able to direct students to achieve optimal learning achievement. Good teacher performance is certainly reflected in their appearance both from the appearance of their academic ability and professional ability to become a teacher, which means being able to manage teaching in the classroom and educating students outside the classroom as well as possible. But in fact, many students are still ineffective in their learning activities even though the teacher's performance has been maximal in teaching, but the effectiveness of students in learning is not optimal, even the teacher academically has fulfilled his professionalism

Learning is a curriculum actualization activity that requires teacher activeness in creating student activities according to a predetermined plan. The main characteristic of learning is the occurrence of effective interaction between students, educators, and learning resources in an environment to create a learning process that is directed at competency standards [10]. Learning can be said to be effective if it can facilitate the acquisition of knowledge of learning skills through the presentation of information and activities designed to help facilitate students in achieving the expected learning goals.

Effectiveness is the level of success that can be achieved from two specific ways or efforts in accordance with the objectives to be achieved. Learning effectiveness can be measured using four indicators, namely the quality of learning, the suitability of learning levels, incentives, and time [11].

Effective learning is a learning process that maximizes the available resources to create a quality process and good quality learning result [12]. Effective learning is not only viewed in terms of learning achievement levels, but must also be seen in terms of learning processes and facilities. 
There are indicators that effective learning is successful in delivering students to achieve predetermined learning objectives, providing interesting learning experiences, involving students actively so that they can support the achievement of learning objectives, and having infrastructure that supports the learning process [13].

Effective learning will be easily realized if a pleasant learning atmosphere is created because the success and achievement of educational goals is very much determined by the quality of learning [9]. Learning objectives are an indicator of the effectiveness of learning. Active student involvement shows the efficiency of learning. The learning process is said to be effective if it achieves the expected goals and students can absorb the subject matter and practice it.

Learning effectiveness is characterized by student activity in learning, especially in organizing and finding information. The more active students are in learning, the more effective the learning will be [13]. The effectiveness of learning is an attempt to maximize the available time as best as possible in order to achieve the expected goals. Effectiveness relates to the implementation of all main tasks, the achievement of goals, the timing, and the active participation of students. See figure 1 below.

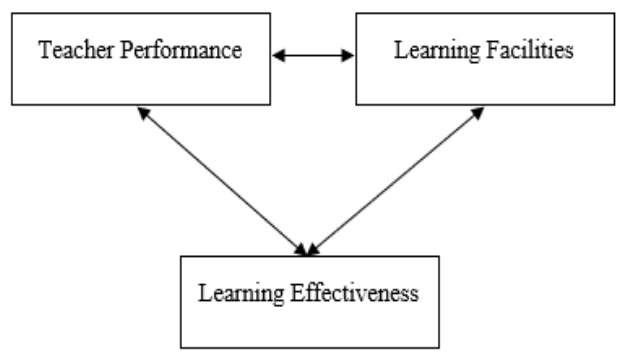

Fig. 1. The effectiveness learning.

\section{METHODS}

This research is a descriptive qualitative research. The source of the material of this study was obtained through interviews by determining key informants followed by interviews with a number of students and teachers using the snowball sampling technique. Data collection was complements by observation techniques, interviews, documentation studies, and making a focus group discussions (FGD) forum with relevant informants at Integrated Islamic Elementary School Manba'ul 'Ulum. Data analysis was performed through data unitization, data categorization and data interpretation.

\section{RESULTS AND DISCUSSION}

The learning that is currently being carried out at Integrated Islamic Elementary School Manba'ul 'Ulum is an online learning system, which us a learning system that is implemented via an internet network without face-to-face meetings. The online learning system must be carried out following the Covid-19 pandemic which has resulted in all areas of life having to be worked from home for a while.

The management of classroom is a teacher's skill to create an optimal learning process. The management of classroom also talks about the teacher's ability to overcome various obstacles found in the learning process [14]. A teacher must be able to ensure the continuity of learning activities even though students are at their own homes. A teacher must also have the ability to make learning media design in an innovative way by utilizing online media. At certain times, the teacher must be able to hold face-to-face meetings with students at designated locations while maintaining Covid-19 health protocols.

The learning system is implemented by utilizing learning facilities that support online learning such as using a cellphone or personal computer. Technically, teachers can hold classes using features available on social media such as WhatsApp, Zoom meeting, Google Classroom or other media that can be used as learning media. That way, teachers can ensure student participation in online meetings simultaneously even though they are in different places.

WhatsApp Group was created as a center for students gathering and exchanging information outside of class schedules. The delivery of material and the face-to-face meeting held in the Zoom Meeting application. The meeting starts at 08.00 WIB until 10.30 WIB. The student assignments are distributed via Google Classroom to make it easier for students to collect assignment. In certain times, Google Classroom is used to share material.

There is another learning method used by the teachers, namely the home visit method. Technically, the teacher makes a schedule to visit the student's house once a week to hold classes. The maximum number of class participants is only five students. The home visit method is implemented so that teachers can still provide learning not only on the cognitive aspects, but also on the psychomotor aspects.

The use of online media in the learning process is an effort to increase the effectiveness and quality of the learning process. The optimal use of online media can improve the quality of student learning results. Delivery of material through online media must remain interactive so that students can still interact and establish communication with other students even though they do not in the face-to-face meeting.

The result showed that the number of students who liked online learning was $21 \%, 29 \%$ liked the mixed learning model, and the remaining $51 \%$ said they liked face-to-face meetings. See figure 2 below. 


\section{The Preferred Learning Model}

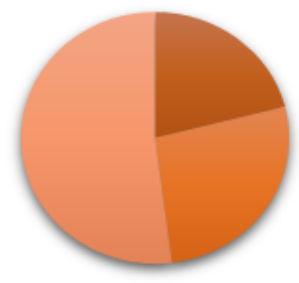

Online

Blended Face to Face

Fig. 2. The preferred learning model.

Students express different experiences when they go through the online class meeting. Some students started that they felt more relaxed, had more time with family at home, and they had more time to rest. The students also conveyed several obstacles in online meetings, including students feel wasteful because the quota used quickly runs out, difficult to understand the subject presented by the teacher, and students feel that social relations with their friends are hampered.

However, the online learning model also has many advantages. With the online method, learning subjects can be conveyed without being limited by space and time, students and teachers can also take advantage of sources that are already available on the internet, and teaching materials are relatively easy to update. In addition, online methods can also increase the independence of students in learning process [15].

The teachers also conveyed some of the obstacles of online learning methods. According to some teachers, through online learning methods, teachers have difficulty conveying the subject maximally because it is limited, both limited by time and space. Online learning methods run the risk of miscommunication and misconceptions between students and teachers. The teacher feels that the implementation of online learning is only focused on giving assignments, while the ration of giving and delivering teaching materials is very small. In addition, access to questions is not as extensive as during face-to-face learning.

Easy a cheap information and telecommunication technology will certainly eliminate the time and space constraints that have been limiting the world of education. There are several consequences that arise as aresult of implementing online learning methods, including (1) students can easily access learning material anywhere without space and time restrictions, (2) students can easily learn and discuss with experts in their fields of interest, (3) learning materials can be easily retrieved in various parts of the world via the internet network without depending on where students study [16]. Athough there are many conveniences offered by online learning methods, the result of the interviews showed that students preferred face-to-face learning.
The availability of internet access is very necessary in online learning, because online learning methods will certainly rely heavily on the internet network. Meanwhile, the internet network access speed in Indonesia is relatively slow. In addition, the availability of the network which is still relatively expensive, is a separate obstacle for the implementation of online learning [17].

The online learning method at Integrated Islamic Elementary School Manba'ul 'Ulum has not been implemented optimally for all stusents because each student has a different learning style. The obstacle in the effectiveness of learning at this time is that the learning facilities owned by students are not evenly distributed. Not all students have smart devices and have an adequate internet network. Economic inequality and internet facilities that have not reached all students certainly hinder the quality of learning results. There are still teachers and students who do not understand technology, do not have the skills to use digital devices, and are not familiar with its use. This obstacle is one of the reasons why the learning process does not work effectively and the results are not optimal. But regardless of these problems, the learning process must still be carried out. The use of online learning methods is the only option so that learning activities can continue amid the Covid-19 pandemic.

\section{CONCLUSION}

Learning facilities are important to support the effectiveness of learning. so that if the learning facilities are used optimally, learning will be more effective. Conversely, if the learning facilities are not used by students, learning will be ineffective. In addition, the teacher's performance which underlies the attitudes, behavior, and teaching profession contributes to effective learning.

The use of learning facilities and teacher performance together has contributed to the effectiveness of learning at Integrated Islamic Elementary School Manba'ul 'Ulum. The more optimal the use of learning facilities and the smarter the teacher's performance in managing the class, the more effective learning will be.

However, due to the current state of the Covid-19 pandemic, the learning facilities at school cannot be used optimally. But adding new facilities that are used for every student and teacher such as cellphones and laptops. Therefore, learning can be said to be less effective because the learning facilities that were originally provided were not used and the learning methods changed.

These results indicate that the use of learning facilities and teacher performance in managing the classroom, it has contributed to the effectiveness of learning at Integrated Islamic Elementary School Manba’ul 'Ulum. 


\section{REFERENCES}

[1] S.R. Haditono, Psikologi Perkembangan. Yogyakarta: Gadjah Mada University Press, 2015.

[2] Engkoswara and A. Komariah, Administrasi Pendidikan, 5th ed. Bandung: Alfabeta, 2020.

[3] S. Danim, Perkembangan Peserta Didik. Bandung: Alfabeta, 2010.

[4] A. Rukmana and A. Suryana, Pengelolaan Kelas. Bandung: UPIPRESS, 2009.

[5] T.L. Gie, Cara Belajar Yang Efisien. Yogyakarta: Pusat Kemajuan Studi, 2002.

[6] O. Hamalik, Proses Belajar Mengajar. Jakarta: Bumi Aksara, 2007.

[7] M.U. Usman, Menjadi Guru Profesional. Bandung: Remaja Rosda Karya, 2006.

[8] Sardiman, Interaksi dan Motivasi Belajar Mengajar. Jakarta: PT. Raja Gafindo Persada, 2005.
[9] A. Akhmadi, Model Pembelajaran Saintifik. Yogyakarta: Araska, 2015.

[10] Haerana, Manajemen Pembelajaran Berbasis Standar Proses Pendidikan. Yogyakarta: Media Akademi, 2016.

[11] R.E. Slavin, Educational Psychology: Theory into Practice (terjemahan), Jakarta: Indeks, 2009.

[12] M. Surya, Psikologi Pembelajaran dan Pengajaran. Bandung: Pustaka Setia, 2004

[13] H. Firman, Ilmu dan Aplikasi Pendidikan. Jakarta: Grasindo, 2007.

[14] U.S. Saud, Pengembangan Profesi Guru. Bandung: Alfabeta, 2009.

[15] N.H. Waryanto, "On-line Learning Sebagai Salah Satu Inovasi Pembelajaran," Pythagoras, vol. 2, pp. 10-23, 2006.

[16] W. Hartanto, "Penggunaan E-learning sebagai Media Pembelajaran," J. Pendidik. Ekon., vol. 10, pp. 1-18, 2016.

[17] G. Hendrastomo, "Dilema dan Tantangan Pembelajaran E-Learning 1," J. Ilm. Pembelajaran, vol. 4, pp. 1-13, 2008 